\title{
The Metabotropic Glutamate Receptor Types 2/3 Inhibit L-Type Calcium Channels via a Pertussis Toxin-Sensitive G-Protein in Cultured Cerebellar Granule Cells
}

\author{
Pascale Chavis, ${ }^{1}$ Haruhiko Shinozaki, ${ }^{2}$ Joel Bockaert, ${ }^{1}$ and Laurent Fagni' \\ ${ }^{1}$ Centre CNRS-INSERM de Pharmacologie et d'Endocrinologie, 34094 Montpellier, Cedex 05, France and ${ }^{2}$ The Tokyo \\ Metropolitan Institute of Medical Science, 3-18-22 Honkomagome, Bunkyo-ku, Tokyo 113, Japan
}

\begin{abstract}
Modulation of $\mathrm{Ca}^{2+}$ channels by metabotropic glutamate receptors (mGluRs) was investigated in cerebellar granule cells using the cell-attached configuration of the patch-clamp technique. Experiments were performed in the absence of external $\mathrm{Ca}^{2+}$ and $\mathrm{Ba}^{2+}$ was used as charge carrier. Bath applied glutamate or $(1 S, 3 R)$ trans-1-aminocyclopentane1,3-dicarboxylic acid (1S,3R t-ACPD) inhibited $\mathrm{Ca}^{2+}$ channels activated by depolarizing pulses. These channels were sensitive to dihydropyridines and displayed a 23 pS conductance. This effect was mimicked by $\left(2 S, 1^{\prime} S, 2^{\prime} S\right.$ )-2-(carboxycyclopropyl)glycine (L-CCG-I), a selective agonist of mGluR2/R3 receptors, but not by quisqualate at a concentration that stimulated inositol phosphate (InsP) synthesis, showing that mGluR1 and mGluR5 did not participate to this mechanism. The phosphodiesterase inhibitor, isobutylmethylxanthine (IBMX), did not alter the action of the mGluR agonists and biochemical measurements showed that $1 S, 3 R$ $t$-ACPD, in the presence of IBMX, decreased CAMP formation in such a small amount that this change could not explain the aimost complete inhibition of the channel activity observed under similar experimental conditions. Moreover, whole-cell recorded $\mathrm{L}$-type $\mathrm{Ca}^{2+}$ currents were inhibited by L-CCG-I, in the presence of $1 \mathrm{~mm}$ intracellular CAMP. These observations were consistent with the hypothesis that cyclic nucleotide second messengers were not involved in this effect. Neither the protein kinase $C$ activator phorbol-12,13dibutyrate (PDBU) nor the phosphatase inhibitor okadaic acid affected the action of 1S,3R $t$-ACPD. The inhibitory action of 1S,3R t-ACPD was abolished by pertussis toxin (PTX). These results suggest that mGluR2 or mGluR3 receptors suppress the activity of L-type $\mathrm{Ca}^{2+}$ channels by a mechanism involving $G_{1}$ or $G_{0}$ proteins. A likely direct effect of G-proteins on the channels is discussed.
\end{abstract}

[Key words: metabotropic glutamate receptors, calcium channe/s, cerebellum, G-protein, patch clamp, mouseJ

The majority of synapses in the mammalian central nervous system use glutamate as neurotransmitter to mediate neuronal excitation. Glutamatergic neurotransmission is mediated by two

\footnotetext{
Received Nov. 23, 1993; revised Apr. 13, 1994; accepted May 12, 1994.

We thank Angie Turner-Madeuf and Jean-Marie Michel for their helpful technical assistance. This work was funded by grants from Bayer France/Troponwerke (Germany), DRET (Grant 91/161), Rhône-Poulenc and Human Frontier.

Correspondence should be addressed to Dr. L. Fagni, C.C.I.P.E., Rue de la Cardonille, 34094 Montpellier, Cedex 05, France.

Copyright $(1994$ Society for Neuroscience $0270-6474 / 94 / 147067-10 \$ 05.00 / 0$
}

types of receptors, the so-called ionotropic and metabotropic receptors (for reviews, see Pin et al., 1993; Seeburg, 1993). The ionotropic receptors are receptor-channel proteins, while metabotropic receptors (mGluRs) are G-protcin-coupled receptors.

Seven different subtypes of mGluRs (mGluR1-mGluR7) have been cloned and characterized. They can be subclassified into three groups, according to their sequence similarities, pharmacological properties, and signaling cascades. In the first group, mGluR 1 and mGluR5 are positively coupled to phospholipase $\mathrm{C}$ and lead to inositol triphosphate (IP3) production. They are more sensitive to quisqualate than to $1 S, 3 R t$-ACPD (Tanabe et al., 1991). The second group consists of mGluR2 and mGluR 3 which are negatively coupled to adenylyl cyclase via a PTXsensitive G-protein. They are poorly activated by quisqualate but more sensitive to $1 S, 3 R t$-ACPD and glutamate. They are selectively activated by micromolar concentrations of L-CCG-I (Ishida et al., 1990; Nakagawa et al., 1990; Hayashi et al., 1992; Pin et al., 1994). Metabotropic GluR4, mGluR6 and mGluR7 form the third group. They are negatively coupled to adenylyl cyclase via a PTX-sensitive G-protein and are selectively activated by L-aminophosphonobutyrate (L-APB) (Nakanishi, 1992; Shigemoto, 1993).

The existence of various mGluR subtypes coupled to different second messenger pathways provides multiple possible coupling mechanisms to ionic channels. Metabotropic GluRs have been reported to inhibit $\mathrm{Ca}^{21}$ channels in cultured or freshly dissociated hippocampal neurons. The pharmacology of the effect was consistent with activation of mainly mGluR1/R5 (Lester and Jahr, 1990; Sahara and Westbrook, 1993; Swartz and Bean, 1992) and L-APB-sensitive receptors in a smaller proportion of cells (Sahara and Westbrook, 1993). Two types of coupling mechanisms have been reported to be involved in this effect. One which displays a rapid onset $(1-3 \mathrm{sec})$ is consistent with membrane-delimited G-protein-coupled mechanism (Lester and Jahr 1990; Swartz and Bean, 1992), another one with a slow time constant ( $>3 \mathrm{~min}$ ) involves a soluble second messenger (Sahara and Westbrook, 1993). The transduction pathways have not yet been identified and the nature of G-proteins involved is still a matter of debate. Indeed the effects have been found to be either PTX insensitive (Lester and Jahr, 1990) or PTX sensitive (Sahara and Westbrook, 1993) in the same cell type.

Moreover, the $\mathrm{Ca}^{2+}$ channel subtypes that are modulated by mGluRs are not well defined. Trans-ACPD has been reported to inhibit L-type $\mathrm{Ca}^{2+}$ channels selectively in neocortical neurons (Sayer et al., 1992), $\mathrm{N}$-type $\mathrm{Ca}^{2+}$ channels in acutely dis- 
sociated CA3 hippocampal neurons (Swartz and Bean, 1992), and both types of $\mathrm{Ca}^{2+}$ channels in cultured hippocampal neurons (Sahara and Westbrook, 1993).

Therefore, the aim of the present work was to elucidate the mechanism of $\mathrm{Ca}^{2+}$ channel inhibition induced by mGluRs in cultured cerebellar granular cells. We focused on three issues: (1) which mGluR subtypes are involved, (2) which second messenger pathway is mobilized, and (3) which $\mathrm{Ca}^{2+}$ channel type is affected. Our results showed that the receptor subtypes involved are mGluR2/R3 and that a major part of the $\mathrm{Ca}^{2+}$ channels are of L-type. The inhibitory pathway involves a PTXsensitive G-protein and a non-membrane-delimited process, since the effect was observed in cell-attached configuration. Nevertheless, none of the classical cytosolic second messengers that are known to modulate $\mathrm{Ca}^{2+}$ channel activity seemed to mediate this effect.

\section{Materials and Methods}

Tissue cultures. Primary cultures of cerebellar granule cells were prepared as previously described (Van-Vliet et al., 1989). Rriefly, 6-d-old mice were decapitated and the brain removed for dissection of cerebellum. After mechanical dissociation of the cerebella, cells were plated $\left(10^{6}\right.$ cclls per dish $)$ in $35-\mathrm{mm}$-diameter culture dishes, previously coated with poly-L-ornithine $(15 \mu \mathrm{g} / \mathrm{ml}$; MW 40,000$)$. The culture medium contained a 1:1 mixture of Dulbecco's minimum essential medium and F-12 nutrient, supplemented with glucose ( $30 \mathrm{~mm}$ ), glutamine ( $2 \mathrm{mM}$ ), sodium bicarbonate ( $3 \mathrm{~mm}$ ), $25 \mathrm{~mm} \mathrm{KCl}$, HEPES ( $5 \mathrm{~mm}$ ), $5 \%$ fetal calf, and $5 \%$ horse decomplemented sera. These cultures have been shown to be highly enriched in neurons (Weiss et al., 1986; Van-Vliet et al., 1989). Granule cells were identified as $5-10 \mu \mathrm{m}$ round cells with thin long neurites and represented $95 \%$ of the cells.

Electrophysiology and data analysis. Cultures were used for electrophysiological and biochemical tests at $10 \pm 1 \mathrm{~d}$ in vitro. For electrophysiological recordings, the culture medium was replaced by an external solution containing $\mathrm{NaCl}(140 \mathrm{~mm}), \mathrm{MgCl}_{2}(2 \mathrm{mM})$, EGTA $(0.1$ $\mathrm{mm}), \mathrm{KCl}(5 \mathrm{~mm})$, HEPES (10 mM), TTX $(0.3 \mu \mathrm{M})$, and D-glucose (10 $\mathrm{mM})(\mathrm{pH} 7.4)$. Drug solutions were prepared in this external medium, $\mathrm{pH}$ adjusted to 7.4 and applied using a rapid bath perfusion system as described elsewhere (Fagni et al., 1991). Unitary currents were recorded under the cell-attached configuration of the patch-clamp technique using an EPC7 amplifier (List, Germany). The recording electrodes were made of glass pipettes filled with a solution consisting of $110 \mathrm{mM} \mathrm{BaCl}, 1 \mu \mathrm{M}$ BAY K 8644 and 10 mM HEPES (pH 7.4; 3-5 MR). Calcium channels were activated by depolarizing pulses of $200 \mathrm{msec}$ duration from 0 to $-60 \mathrm{mV}$ pipette potential. These values corresponded to -60 and 0 $\mathrm{mV}$ membrane potentials, respectively, assuming that resting membrane potential of the recorded cells was $-60 \mathrm{mV}$. This assumption was verified in 10 cells, under whole-cell configuration, by using the current-clamp recording method, with pipettes filled with a $130 \mathrm{~mm}$ $\mathrm{KCl}$ solution: membrane potential was found to be $-60 \pm 7 \mathrm{mV}$ (mean $\pm \mathrm{SD}$ ).

Only one patch per cell was performed. Unitary current recordings were filtered at $1 \mathrm{kHz}$ with an eight pole Bessel filter (Frequency Devices, Haverhill, MA) and sampled at $5 \mathrm{KHz}$ on an AT-3 IBM computer. Linear leak and capacitive currents were digitally subtracted from records before analysis. The threshold for detecting opening and closing transitions was set at $50 \%$ of the open level of each event. Data were thus reduced to values corresponding to open times, close times, and amplitudes. These values provided a way of calculating open probabilities $\left(N P_{o} ; N=\right.$ putative number of activated channels, $P_{o}=$ putative unitary open probability), amplitude and open time distributions using the 5.5 pCLAMP software of Axon Instrument (Burlingame, CA). $N P_{\text {o }}$ values were calculated by dividing the integrated time during which channels stayed open by the duration of the depolarization step, for a given level of opening. Mean amplitude of unitary currents was calculated by using Gauss relation fitted by least squares to amplitude distribution histogram. Sums of decaying exponentials were fitted by least squares to each open time distribution histogram.

Macroscopic $\mathrm{Ca}^{2+}$ currents $\left(I_{\mathrm{Ca}}\right)$ were elicited by $450 \mathrm{msec}$ depolarizing pulses from -80 to $0 \mathrm{mV}$ and recorded using whole-cell patch pipettes filled with a solution of the following composition: Cs-acetate
(140 mM), $\mathrm{MgCl}_{2}$ (2 mM), EGTA (20 mM), HEPES (10 mM), ATP-Na ( 2 mM), cAMP (1 mM) (pH 7.2). In some experiments, ATP and cAMP were omitted in the intracellular medium. The presence of these nucleotides in the recording pipette considerably improved the stability of $I_{\mathrm{Ca}}$ by minimizing rundown of the current (see also Slesinger and Lansman, 1991). The external medium contained Na-acetate (140 mM), Baacetate (20 mM), TEA-Cl (20 mM), HEPES (10 mM), TTX $(0.3 \mu \mathrm{M})$, and D-glucose (10 mM) (pH 7.4). Linear leak and capacitive currents were digitally subtracted from records before analysis. Amplitude of $I_{\mathrm{Ca}}$ was measured at the current peak and percentage variations in the presence of drugs were calculated versus control (in the absence of drug). Comparable results were obtained when measurements were performed on the plateau phase of $I_{\mathrm{Ca}}$

In both cell-attached and whole-cell recording configurations, depolarizing pulses were continuously applied at a rate of $0.2 \mathrm{~Hz}$ throughout the course of the experiment. Controls were taken and then agonists were perfused for $5 \mathrm{~min}$ before quantification of the effects and washed out. Data were expressed as mean \pm SD and Student's $t$ tests were used for statistical analyses.

Cyclic AMP formation. The method presently used to measure cyclic AMP formation was adapted from the one previously described for cultured striatal neurons (Weiss et al., 1985). Briefly, cells were incubated at $37^{\circ} \mathrm{C}$ with ${ }^{3} \mathrm{H}$-adenine for $2 \mathrm{hr}$. Then, cultures were washed and incubated with $1 \mathrm{~mm}$ IBMX and $1 S, 3 R t$-ACPD in $1 \mathrm{ml}$ of HEPESbuffered saline (146 mM NaCl, $4.2 \mathrm{mM} \mathrm{KCl}, 0.5 \mathrm{~mm} \mathrm{MgCl}$, D-glucose $0.1 \%$, BSA $1 \%, 20 \mathrm{~mm}$ HEPES, pH 7.2). Calcium was omitted in this buffer in order to avoid any $\mathrm{Ca}^{2+}$ influx. The reaction was stopped by replacing the incubation medium with ice-cold $5 \%$ trichloroacetic acid. ${ }^{3} \mathrm{H}$-ATP and ${ }^{3} \mathrm{H}$-cyclic AMP were separated by sequential chromatography on Dowex and alumina columns. Cyclic AMP formation was expressed as percent conversion of ${ }^{3} \mathrm{H}$-ATP to ${ }^{3} \mathrm{H}$-cyclic AMP.

Inositol phosphate formation. InsP formation was measured as previously described (Sladeczek et al., 1985). Briefly, after $3 \mathrm{~d}$ in vitro, cultured neurons were incubated for $7 \mathrm{~d}$ with ${ }^{3} \mathrm{H}$-myo-inositol. The culture medium was then replaced with HEPES-buffered saline (146 $\mathrm{mm} \mathrm{NaCl}, 4.2 \mathrm{~mm} \mathrm{KCl}, 0.5 \mathrm{~mm} \mathrm{MgCl}_{2}, 1.1 \mathrm{~mm} \mathrm{CaCl}, 0.1 \%$ glucose, $10 \%$ BSA, 20 mm HEPES, $\mathrm{pH}$ 7.2) and neurons were incubated for 10 min in $10 \mathrm{~mm} \mathrm{IiCl}$ in order to block InsP degradation. The reaction was performed at $37^{\circ} \mathrm{C}$ for $30 \mathrm{~min}$, in the presence of glutamate-pyruvate transaminase $(1 \mathrm{U} / \mathrm{ml})$ and pyruvic acid $(1 \mathrm{~mm})$, in order to avoid any contamination by endogenous glutamate. The reaction was stopped by replacing the incubation medium with ice-cold $5 \%$ perchloric acid. Inositol phosphates were extracted and separated by ion exchange chromatography.

Materials. Metabotropic GluR agonists and antagonists were purchased from Tocris Neuramin (Essex, England), except for L-CCG-I, which was prepared according to the method described by Shimamoto et al. (1991), and $1 S, 3 R t$-ACPD, which was generously given by $\mathrm{K}$ Curry (University of British Columbia, Department of Physiology, Vancouver, Canada). Pertussis toxin was obtained from List Biochemical Laboratories (USA), and (S)-BAY K 8644 was a generous gift from Bayer France/Troponwerke (Germany). All other pharmacological agents used in this study were obtained from Sigma.

\section{Results}

\section{Effect of $m G$ luR agonists on $\mathrm{Ca}^{2+}$ channels}

In 6 of 10 patches, application of $100 \mu \mathrm{M} 1 S, 3 R t$-ACPD outside the patch decreased $N P_{o}$ by $61 \pm 7.9 \%$ (significant effect at $p \leq$ 0.001 ) and in 4 of 10 patches, completely inhibited voltageactivated $\mathrm{Ca}^{2+}$ channels (Fig. 1). Such effects appeared after 2$5 \mathrm{~min}$ application and lasted for up to $15 \mathrm{~min}$ upon washout of the agonist. In separate experiments $(n=6)$, continuous recording over a period of $30 \mathrm{~min}$, in the absence of agonist, did not display any significant rundown of the channel activity, indicating that the $1 S, 3 R t$-ACPD-induced inhibition of the $\mathrm{Ca}^{2+}$ channel resulted from a specific action of the drug and not from a time-dependent inactivation of the channel.

As illustrated in Figure $2 A$, inhibition of voltage-activated $\mathrm{Ca}^{2+}$ channels was also found with $1 \mu \mathrm{M}$ L-CCG-I. In five of five patches, this agonist completely inhibited the $\mathrm{Ca}^{2+}$ channel activity after $1-3$ min exposure to the agonist. Five minutes 
CONTROL
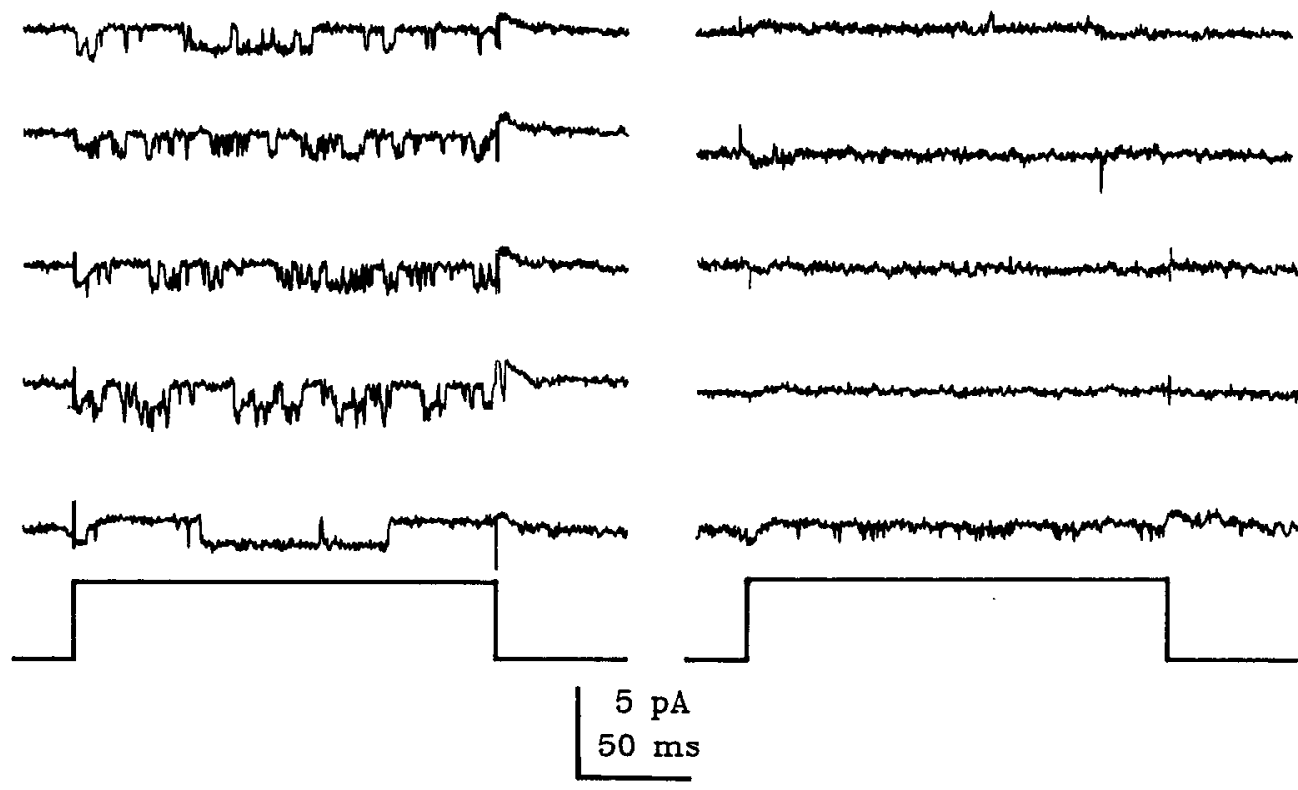

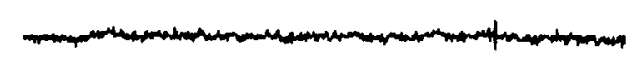

$t-A C P D$
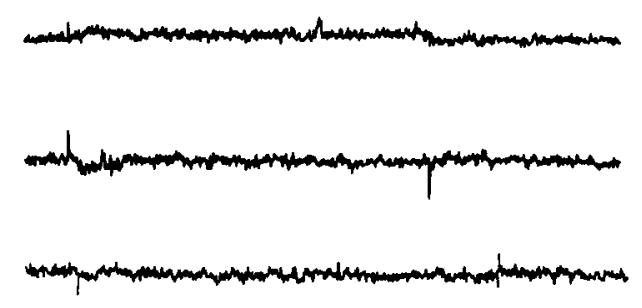

Figure 1. Suppression of $\mathrm{Ca}^{2+}$ channel activity by $1 S, 3 R t$-ACPD: five representative traces of unitary $\mathrm{Ca}^{2+}$ currents obtained before (left) and after 5 min perfusion of $1 S, 3 R t$-ACPD (100 $\mu \mathrm{M})($ right). This effect was representative of three other patches. In this and the following figures, the lower traces represent voltage steps from 0 to -60 $\mathrm{mV}$ pipette potential (equivalent to a step from -60 to $0 \mathrm{mV}$ membrane potential). application of glutamate $(100 \mu \mathrm{M})$, in the presence of $50 \mu \mathrm{M}$ CNQX and $10 \mu \mathrm{M} \mathrm{CCP}$, reduced $N P_{o}$ by $83 \pm 12 \%(n=5)$ (Fig. $2 B$ ). Quisqualate $(5 \mu \mathrm{M}$; Fig. $2 C)$ and L-APB (1 mM; Fig. $2 D)$ did not affect $N P_{o}$ of the $\mathrm{Ca}^{2+}$ channel ( $n=5$ for each drug).

\section{Characterization of the $\mathrm{mGluR}$-sensitive $\mathrm{Ca}^{2+}$ channel}

The biophysical properties of the $t$-ACPD-sensitive $\mathrm{Ca}^{2+}$ channel were examined in 10 patches, before application of $1 S, 3 R$ $t$-ACPD. The mean conductance of the channel measured between -70 and $-30 \mathrm{mV}$ pipette potential $(+10$ and $-30 \mathrm{mV}$ membrane potential, respectively; Fig. $3 \mathrm{~A}$ ) was found to be 23.4 $\pm 0.2 \mathrm{pS}$. This conductance did not significantly change in the presence of $1 S, 3 R t$-ACPD, indicating that the agonist did not affect membrane potential of the recorded cells.

In five cells, $N P_{o}$ of the $\mathrm{Ca}^{2+}$ channel was measured at different membrane potentials. One example is illustrated in Figure $3 B$ where $N P_{o}$ progressively increased as membrane was depolarized (as pipette potential became more negative), indicating a strong voltage dependence of the recorded channel and a threshold potential for activation of $-30 \mathrm{mV}$ pipette potential $(-30$ $\mathrm{mV}$ membrane potential). Open time distribution of the channel was best fitted to two exponentials with time constants of 0.6 and $4.4 \mathrm{msec}$, respectively (Fig. $3 C$ ). This indicated two pathways of closure from the open state of the channel.

The pharmacological properties of the trans-ACPD sensitive $\mathrm{Ca}^{2+}$ channel were also studied. The $\mathrm{Ca}^{2+}$ channel was first identified by its unitary conductance and threshold activation potential. The cell was then exposed to $0.1 \mu \mathrm{M}$ nifedipine, applied outside the recorded patch. The dihydropyridine completely and reversibly blocked the recorded $\mathrm{Ca}^{2+}$ channel in all of the patches tested ( $n=4$; Fig. $3 D$ ). Note that all experiments reported in this study were performed in the presence of $1 \mu \mathrm{M}$ BAY K 8644 in the recording pipette solution. Under these conditions, $83 \%$ of the patches (13 over 16 patches) displayed the $\mathrm{Ca}^{2+}$ channel activity characterized here above. In 12 patches where BAY K 8644 was omitted in the pipette, only four of them displayed $\mathrm{Ca}^{2+}$ channel activity similar to that found in the presence of BAY K 8644 (Fig. $3 E$ ). In these four patches, $N P_{o}$ of the $\mathrm{Ca}^{2+}$ channels was $82 \pm 12 \%$ lower than $N P_{o}$ found in the presence of BAY K 8644. Indeed, in these patches most of the applied depolarizing pulses failed to elicit channel activity. In all the patches where dihydropyridine agonist and antagonist affected $\mathrm{Ca}^{2+}$ channels, $1 S, 3 R t$-ACPD $(100 \mu \mathrm{M})$ inhibited these channels.

\section{Sensitivity of the mGluR effect to PTX}

Cultures prepared from same animals were separated in two groups: control cells (untreated) and cells exposed over night to PTX $(200 \mathrm{ng} / \mathrm{ml})$. In PTX-treated cells, $N P_{o}$ of the $\mathrm{Ca}^{2+}$ channel was $0.25 \pm 0.18$ in the absence of $m$ GluR agonist and $0.35 \pm$ $0.14(n=5)$ after 15 min perfusion of trans-ACPD $(500 \mu \mathrm{M})$. These two mean values were not significantly different from each other ( $p \leq 0.05$ ) (Fig. 4). The PTX treatment did not change mean unitary current amplitudes $(1.2 \pm 0.11 \mathrm{pA} ; n=6)$ measured at $-60 \mathrm{mV}$ pipette potential ( $0 \mathrm{mV}$ membrane potential), or their threshold activation potential $(-30 \mathrm{mV}$ pipette or membrane potential).

Patches performed in control cells displayed voltage-activated $\mathrm{Ca}^{2+}$ channels that were inhibited by bath applied $1 S, 3 R t$ $\mathrm{ACPD}\left(100 \mu \mathrm{M} ; N P_{o}\right.$ in the absence of drug $=0.43 \pm 0.29 ; N P_{o}$ after 5 min perfusion of $1 S, 3 R t$-ACPD $=0.11 \pm 0.13 ; n=6$ ), indicating a normal sensitivity of the cultures to the mGluR agonist in the absence of PTX treatment.

\section{Pharmacology of phospholipase C-coupled mGluRs in cerebellar granule cells}

Inositol phosphate formations induced by glutamate, $1 S, 3 R$ $t$-ACPD and quisqualate were measured and compared (Fig. 5). 
$\mathbf{A}$

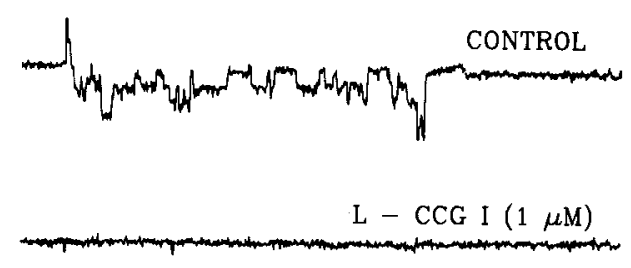

C

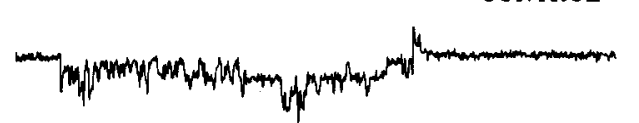

Figure 2. Effects of mGluR agonists on $\mathrm{Ca}^{2+}$ channels. Recordings $A$ and $B$ were obtained from the same patch and $C$ and $D$ from a different patch. $G l u$, Quis, and $A P 4$ stand for glutamate, quisqualate, and L-APB, respectively. Test traces of unitary $\mathrm{Ca}^{2+}$ currents were obtained after $5 \mathrm{~min}$ perfusion of the corresponding agonists. Calibration: 5 $\mathrm{pA}, 50 \mathrm{msec}$ (for all traces).

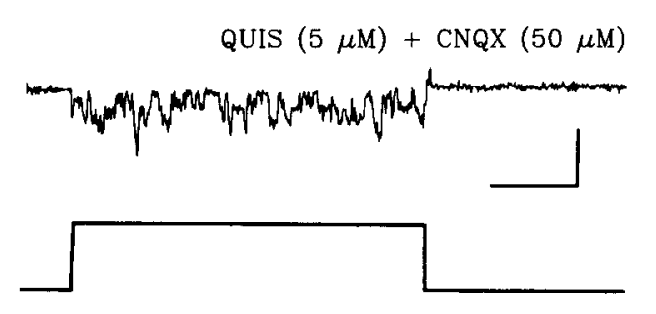

B

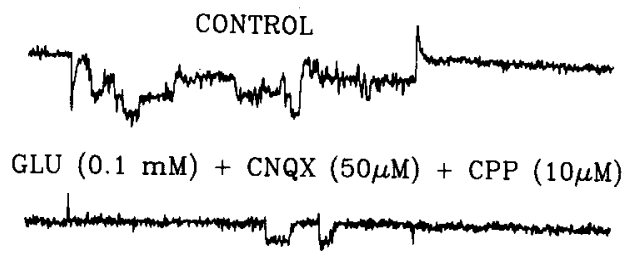

D
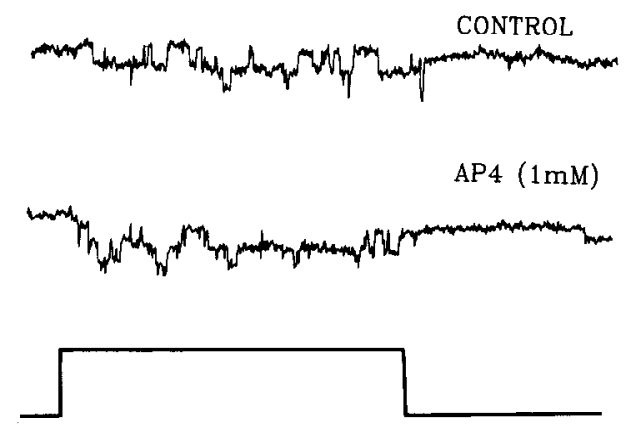

The rank of potency of these agonists was quisqualate $>$ glutamate $>1 S, 3 R$-trans-ACPD. Here, it is interesting to consider concentrations of these agonists that were used in our electrophysiological tests. Thus, $100 \mu \mathrm{M}$ glutamate and $5 \mu \mathrm{M}$ quisqualate increased InsP formation by $100 \%$, whereas $100 \mu \mathrm{M}$ $1 S, 3 R t$-ACPD increased InsP formation by only $15 \%$. One micromolar L-CCG-I did not induce any detectable InsP formation.

\section{Effect of $1 S, 3 R$-ACPD on IBMX-induced increase in $C A M P$ production}

Dihydropyridine-sensitive $\mathrm{Ca}^{2+}$ channels are up-regulated by D1 dopaminergic and $\beta$-adrenergic receptor-stimulated cAMPdependent phosphorylation in bovine chromaffin cells (Artalejo et al., 1990) and frog cardiomyocytes (Hartzell et al., 1991), respectively. Because mGluR2, mGluR3, mGluR4 and mGluR6 are negatively coupled to adenylyl cyclase, we examined the possibility that the mGluR agonist-induced inhibition of $\mathrm{Ca}^{2+}$ channels could result from a net decrease in the rate of cAMPinduced channel phosphorylation due to a mGluR-induced cAMP depletion. Five minutes incubation of granule cells in the presence of the phosphodiesterase inhibitor, IBMX ( $1 \mathrm{mM})$, resulted in a substantial increase in $\mathrm{Ca}^{2+}$ channel activity (Fig. $6 A)$. Indeed, $N P_{o}$ increased by $63.3 \pm 9.9 \%(n=5)$ during IBMX application (this effect was significant at $p \leq 0.001$ ). The same cells were then exposed for $5 \mathrm{~min}$ (still in the presence of IBMX) to $1 S, 3 R t$-ACPD $(100 \mu \mathrm{M})$ and this reduced $N P_{o}$ of the channels by $73.0 \pm 11.3 \%$ (Fig. $6 A$ ).

In order to quantify the effective variation in cAMP concentration produced by the IBMX treatment, intracellular cAMP formation was measured over $5 \mathrm{~min}$ exposure to the phosphodiesterase inhibitor. Figure $6 B$ shows that under such conditions, cAMP progressively accumulated with time. In separate experiments, we verified that this increase in cAMP synthesis was stabilized after $5 \mathrm{~min}$ exposure to the drug (not shown). Therefore, we measured the effect of $1 S, 3 R t$-ACPD $(100 \mu \mathrm{M})$ after a 5 min IBMX treatment. When $1 S, 3 R t$-ACPD $(5 \mathrm{~min}$ exposure) was added to the IBMX containing medium, we observed only a slight decrease in the percentage conversion of ${ }^{3} \mathrm{H}$-ATP to ${ }^{3} \mathrm{H}$-cAMP (from $0.62 \pm 0.01 \%$ to $0.53 \pm 0.01 \%$; Fig. $6 B)$.

\section{Role of protein kinase $C$ on $\mathrm{t}-A C P D$-induced inhibition of $C a^{2+}$ channel}

Protein kinase C (PKC) has been shown to exert inhibitory effects on dihydropyridine-sensitive $\mathrm{Ca}^{2+}$ channels in cardiac cells (Lacerda et al., 1988). Activation of PKC by phorbol esters also suppresses a high threshold $\mathrm{Ca}^{2+}$ current in hippocampal pyramidal neurons (Doerner et al., 1990). Therefore, we tested the role of PKC in the $1 S, 3 R t$-ACPD-mediated inhibition of $\mathrm{Ca}^{2+}$ channels, in our preparation. Treatment of cerebellar neurons with the PKC activator, $\mathrm{PDBU}(0.1 \mu \mathrm{M}, 15 \mathrm{~min})$, did not significantly affect the activity of $\mathrm{Ca}^{2+}$ channels (Table 1; compare first and second columns). In the same cells $(n=5), 5 \mathrm{~min}$ perfusion of $1 S, 3 R t-A C P D(100 \mu \mathrm{M})$, in the presence of PDBU, still strongly inhibited the recorded $\mathrm{Ca}^{2+}$ channel (Table 1; compare second and third columns).

\section{Effect of phosphatase inhibitor on $\mathrm{t}-A C P D$-induced inhibition of $\mathrm{Ca}^{2+}$ channel}

We finally tested the hypothesis that mGluR-induced $\mathrm{Ca}^{2+}$ channel inhibition resulted from dephosphorylation of the channel. Okadaic acid was bath applied for $20 \mathrm{~min}$ at concentration (80 nM) that inhibits phosphatases 1 and $2 \mathrm{~A}$ (Armstrong and White 1992). This drug alone slightly increased the activity of $\mathrm{Ca}^{2+}$ channels (Fig. 7) as expected from a drug that would reduce channel dephosphorylation. Following the okadaic acid treatment, 5 min application of $1 S, 3 R t$-ACPD $(100 \mu \mathrm{M})$ was then tested in the same cell. The mGluR agonist completely inhibited $\mathrm{Ca}^{2+}$ channel activity (Fig. 7). Similar results were obtained in seven different cells. 

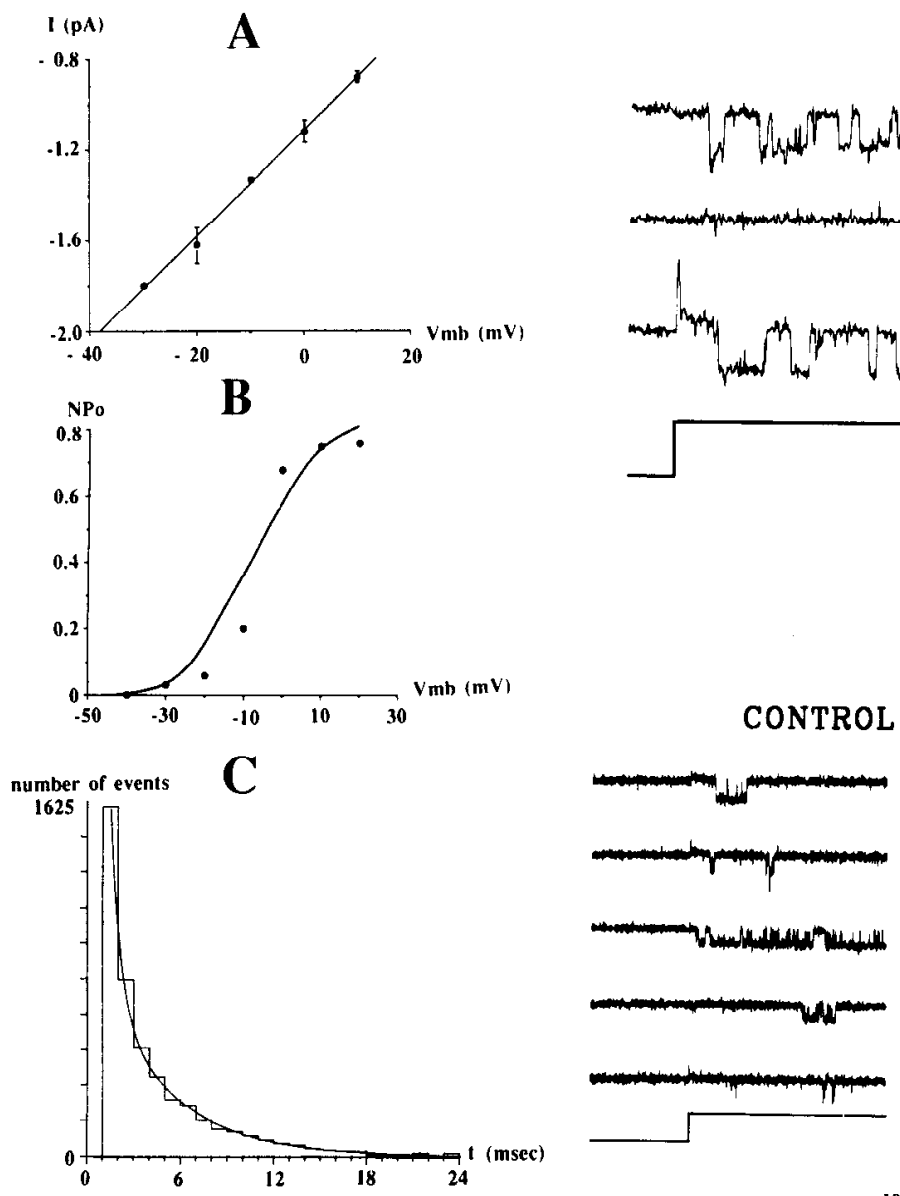

E
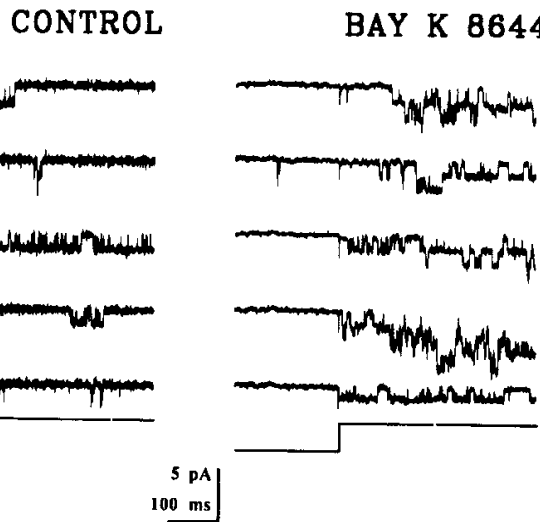

Figure 3. Pharmacological and biophysical properties of the mGluR-sensitive $\mathrm{Ca}^{2+}$ channel. $A$, Current-voltage relationship obtained from 10 patches displaying mGluR-sensitive $\mathrm{Ca}^{2+}$ channels ( $V m b=$ membrane potential). The continuous line is a regression with a characteristic slope of 23.4 (conductance in $\mathrm{pS}$ ) fitted to data by least squares. $B, N P_{o}$ of a single mGluR-sensitive $\mathrm{Ca}^{2+}$ channel expressed as a function of membrane potential. Data fitted by least squares the following Boltzmann relation (continuous line on the figure) $y=\left(1+\exp ^{-0.1089(V o+1.14)}\right)^{-1}$, indicating an $e$-fold change $N P_{o}$ per 9.18 $\mathrm{mV}$ change in membrane potential and a characteristic voltage for half-activation $(\mathrm{Vo})$ of $-1.14 \mathrm{mV}$. Similar results were obtained from four other patches. $C$, Open time distribution of a single $\mathrm{Ca}^{2+}$ channel with gating similar to that in $E$ in the presence of BAY $\mathrm{K} 8644$. The solid line is the best-fitting sum of two exponential components with time constants of 0.6 and $4.4 \mathrm{msec}$ and weights of 2322 and 1499 , respectively. $D$, Application of nifedipine $(0.1$ $\mu \mathrm{M})$ outside the patch completely and reversibly blocked the $\mathrm{Ca}^{2+}$ channel activity. Similar dihydropyridine sensitivity was obtained from three other cells. $E$, Unitary $\mathrm{Ca}^{2+}$ currents recorded in the absence and presence of BAY K $86644(1 \mu \mathrm{M})$. Note the increase in channel activity in the presence of the dihydropyridine agonist.

\section{PTX (200 ng/ml)}

CONTROL

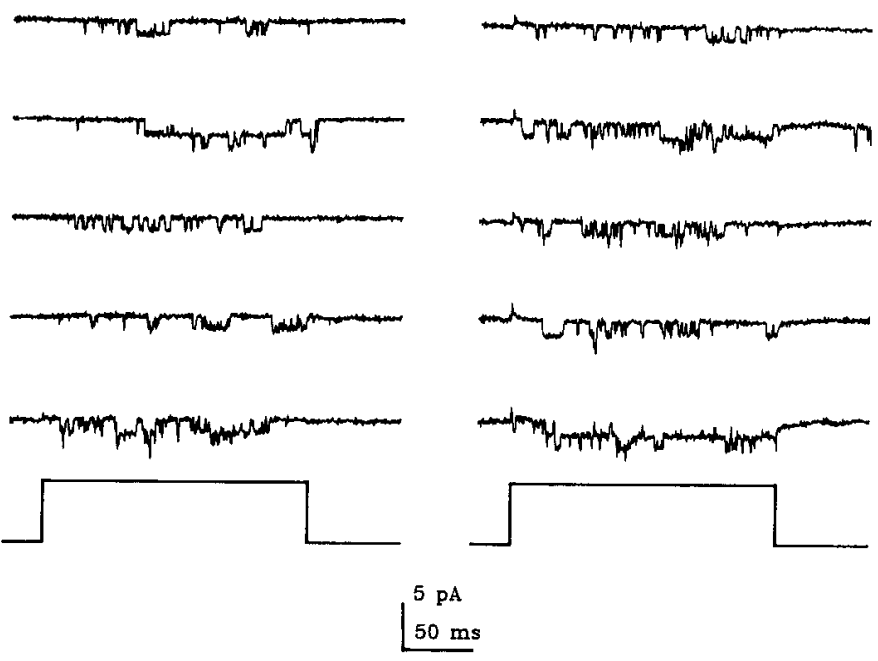

Figure 4. Suppression of the $1 S, 3 R t$-ACPD-induced inhibition of $\mathrm{Ca}^{2+}$ channels by PTX $(200 \mathrm{ng} / \mathrm{ml})$. Five representative traces of unitary $\mathrm{Ca}^{2+}$ currents obtained before (left) and after 5 min perfusion of $1 S, 3 R$ $t$-ACPD $(100 \mu \mathrm{M})(r i g h t)$. This effect was representative of five other patches. The lower traces represent voltage steps from 0 to $-60 \mathrm{mV}$ pipette potential.

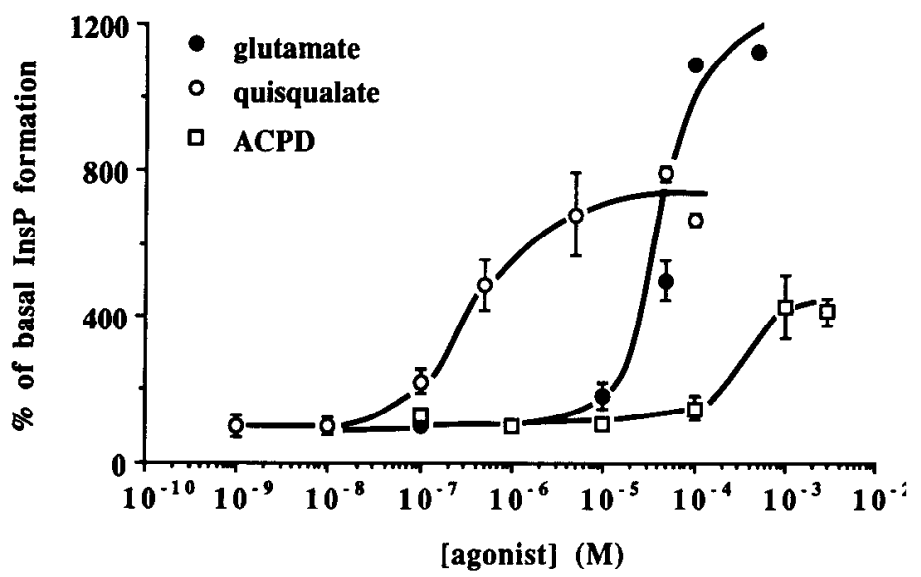

Figure 5. Dose-response curves for glutamate-, quisqualate-, and $1 S, 3 R$ $t$-ACPD-induced InsP formation in cultured cerebellar granule cells. Experiments with glutamate were performed in the presence of $50 \mu \mathrm{M}$ CNQX and $10 \mu \mathrm{M}$ CPP in order to avoid both AMPA and NMDA receptor activation. Basal InsP formation was $146 \pm 18 \mathrm{dpm}$. Experiments with quisqualate were performed in the presence of $50 \mu \mathrm{M} \mathrm{CNQX}$ in order to avoid AMPA receptor activation. Basal InsP formation was $1560 \pm 193.2 \mathrm{dpm}$. In experiments with $1 S, 3 R t$-ACPD basal InsP formation was $1580 \pm 123 \mathrm{dpm}$. For all curves, each point represents the mean \pm SEs of triplicates. 
A

CONTROL
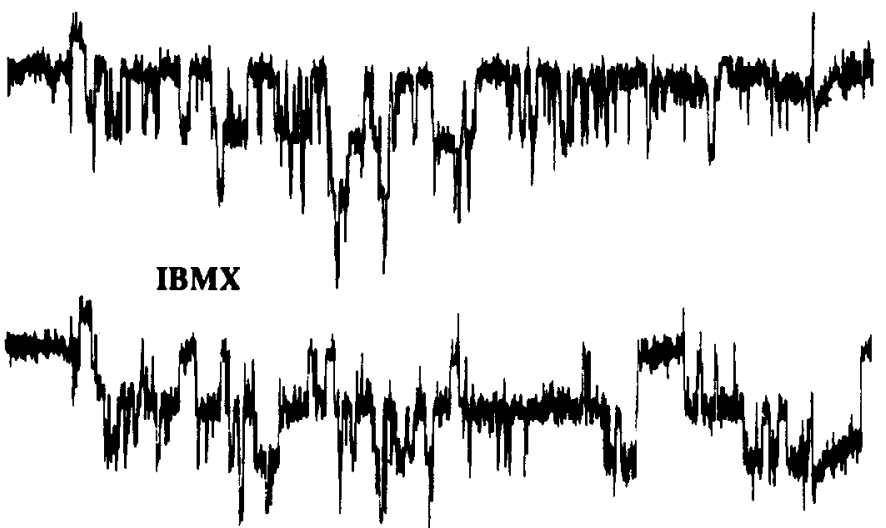

IBMX + ACPD

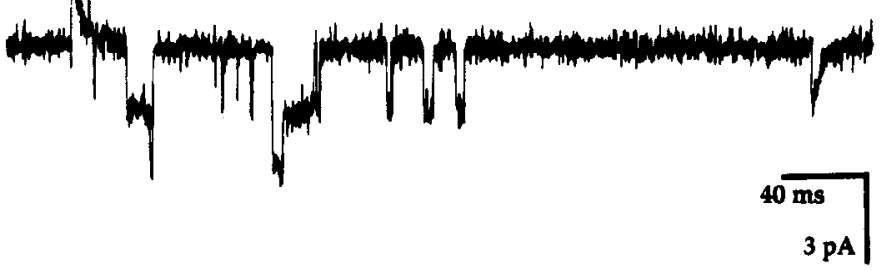

$\mathbf{0} \mathrm{mV}$

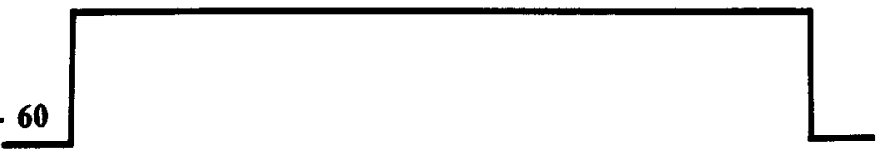

B

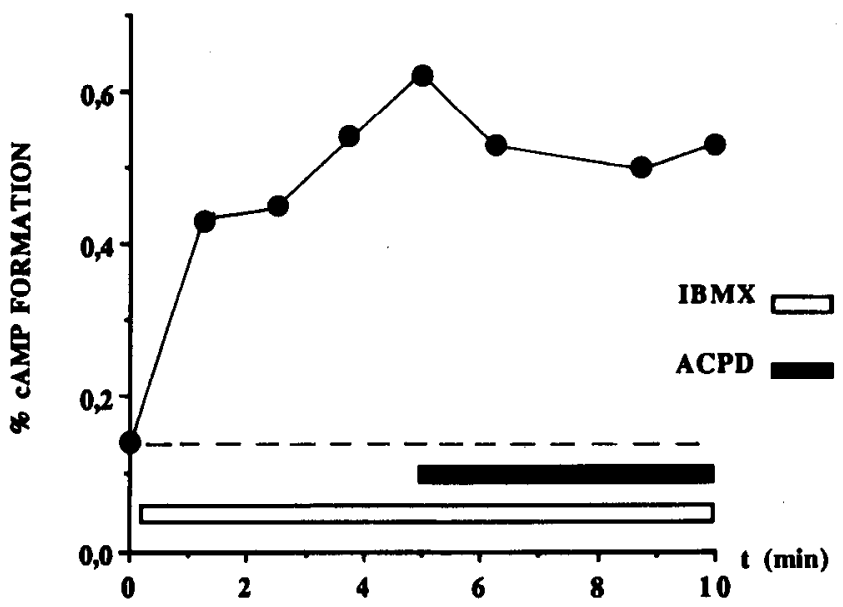

Figure 6. Intracellular cAMP depletion does not induce $\mathrm{Ca}^{2+}$ channel inhibition. $A$, Cell-attached recordings obtained from a same patch under control conditions (upper trace), after $5 \mathrm{~min}$ application of $1 \mathrm{~mm}$ bath applied IBMX (middle trace) and after $5 \mathrm{~min}$ application of 100 $\mu \mathrm{M} 1 S, 3 R t$-ACPD in the presence of IBMX (lower trace). This example is representative of four other patches. $B$, Cells were treated for $5 \mathrm{~min}$ with IBMX (1 mM). Some were harvested at indicated times and cAMP formation was measured as described in Materials and Methods; 100
Table 1.

$N P_{0}$

control

(in the absence

of drug)

$N P_{0}$

$0.38 \pm 0.01$

in the presence

$N P_{0}$

$0.24 \pm 0.05$

$0.50 \pm 0.03$ of PDBU + ACPD

$0.44 \pm 0.08$

$0.21 \pm 0.04$

$0.04 \pm 0.03$

$0.30 \pm 0.01$

$0.43 \pm 0.01$

$0.15 \pm 0.04$

$0.38 \pm 0.02$

$0.34 \pm 0.02$

$0.12 \pm 0.06$

$0.11 \pm 0.04$

$0.36 \pm 0.02$

0.00

The phorbol ester, PDBU, does not affect the action 1S,3R t-ACPD on $\mathrm{Ca}^{2+}$ channels. Each table value is a mean $( \pm S D)$ of cell-attached recorded $\mathrm{Ca}^{2}$ ' channel NPo calculated from 60 successive pulses, in five different cells (each line was obtained from a same patch), each of them recorded in the following three different conditions (columns): under control conditions (first column), after $15 \mathrm{~min}$ application of PDBU $(0.1 \mu \mathrm{M}$, second column), and after $5 \mathrm{~min}$ application of $1 \mathrm{~S}, 3 \mathrm{R}$ $\mathrm{t}-\mathrm{ACPD}(100 \mu \mathrm{M})$ in the presence of PDBU (third column).

\section{Effects of $m$ GluR agonists on the macroscopic $\mathrm{Ca}^{2+}$ current}

Different types of $\mathrm{Ca}^{2+}$ channels have been described in cerebellar granule cells (Forti and Pietrobon, 1993; Pietrobon et al., 1993; Zhang et al., 1993; Bossu et al., 1994). The possibility that mGluR stimulation could affect non-L-type $\mathrm{Ca}^{2+}$ channels was therefore examined on macroscopic $I_{\mathrm{Ca}}$ recorded in the whole-cell configuration of the patch-clamp technique. Note that these experiments were performed in the presence of millimolar concentrations of intracellular cAMP and ATP. Indeed, the very rapid rundown of $I_{\mathrm{Ca}}$ obtained in the absence of these nucleotides in the recording pipette rendered difficult the study of mGluRs on this current.

L-CCG-I $(1 \mu \mathrm{M})$ inhibited $I_{\mathrm{Ca}}$ by $40.7 \%( \pm 13.2 \%, n=12)$. The effect appeared within 2-5 min perfusion of the drug as shown in Figure $8 \mathrm{~A}$ and could last for up to $15 \mathrm{~min}$. The action of $\mathrm{L}-\mathrm{CCG}-\mathrm{I}$ on $I_{\mathrm{Ca}}$ was compared to the one of nifedipine at a concentration $(10 \mu \mathrm{M})$ of this dihydropyridine that blocked all L-type $\mathrm{Ca}^{2+}$ channels. The inhibitory action of nifedipine was faster (Fig. $8 B$ ) and significantly smaller (27.5\% $\pm 10.2 \% ; n=$ $12 ; p \leq 0.05$ ) than the one of L-CCG-I. When $I_{\mathrm{Ca}}$ was first inhibited by L-CCG-I, nifedipine did not induce significantly larger inhibition of the current $(n=10$, Fig. $8 A$ ), indicating that L-CCG-I blocked all the L-type $\mathrm{Ca}^{2+}$ current. However, when $I_{\mathrm{Ca}}$ was first inhibited by nifedipine, L-CCG-I did induce significant further inhibition $(11.7 \% \pm 8.2 \%$ more inhibition, $n=$ 10 ) of the current (Fig. 8B), indicating that L-CCG-I blocked also non-L-type $I_{\mathrm{Ca}}$. Comparable results were obtained with nimodipine instead of nifedipine $(n=5)$.

\section{Discussion}

The present findings show that mGluRs negatively coupled to adenylyl cyclase inhibited L-type $\mathrm{Ca}^{2+}$ channels via a pertussis toxin-sensitive pathway, in cultured cerebellar granule cells. Most of these results were obtained under cell-attached configuration, a recording condition that was the most suitable for the purpose of this work, considering the fact that a second messenger system was likely to be involved.

It has becn previously shown that low concentrations of mGluR

$\mu \mathrm{M} 1 S, 3 R t$-ACPD was added after the $5 \mathrm{~min}$ IBMX treatment. cAMP accumulation was also measured at the indicated times during the $1 S, 3 R$ $t$-ACPD application. 
CONTROL OKADAIC ACID $\quad t-A C P D$

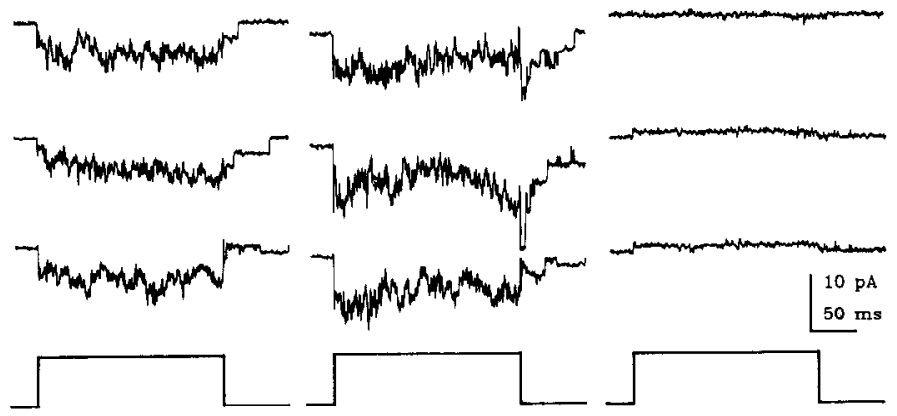

Figure 7. The phosphatase inhibitor okadaic acid does not affect the action $1 S, 3 R t$-ACPD on $\mathrm{Ca}^{2+}$ channels. Recordings were obtained from a same cell-attached macropatch before (left traces) and after $20 \mathrm{~min}$ okadaic acid treatment, in the absence (middle trace) and following 5 min perfusion of $100 \mu \mathrm{M} 1 S, 3 R t$-ACPD (right traces). These results are representative of six other patches.

agonists induce cell depolarization in slice preparation (Stratton et al., 1989; Charpak et al., 1990; Pacellli and Kelso, 1991). However, in the present experiments, the amplitude of unitary currents was identical before and during agonist application. This ruled out the possibility that the mGluR-induced inhibition of the channels resulted from depolarization of the cell. Indeed, we have previously shown that $t$-ACPD does not evoke significant inward current in our preparation (Manzoni et al., 1990a), and thereforc no depolarizing effect of the drug should have been expected in the present study.

Our experiments were designed to determine which subtype of mGluR was involved in $\mathrm{Ca}^{2+}$ channel inhibition. The following arguments are against the involvement of $\mathrm{mGluR} 1 / \mathrm{R} 5$, but rather in favor of mGluR2/R3.

(1) Quisqualate is much more potent at mGluR $1 / \mathrm{R} 5$ than at mGluR2/R3 (Manzoni et al., 1991; Nakanishi 1992; Prezeau et al., 1992; Tanabe et al., 1992). This agonist was found to be the most potent in inducing InsP formation, a typical mGluR 1/ $\mathrm{R} 5$ response. Nevertheless, used at a concentration inducing maximal InsP formation, quisqualate was unable to inhibit $\mathrm{Ca}^{2+}$ channel activity. This shows that the inhibition of $\mathrm{Ca}^{2+}$ channels could not be mediated by mGluR1/R5.

(2) We found glutamate to be an order of magnitude more potent than $1 S, 3 R t$-ACPD in inducing InsP formation, whereas these agonists have been shown to be equipotent at mGluR2/ R3 receptors in transfected CHO cells (Nakanishi, 1992; Tanabe et al., 1992). We also found these compounds to be roughly equally potent in inhibiting $\mathrm{Ca}^{2+}$ channels, suggesting that this effect was mediated by mGluR2/R3 rather than mGluR1/R5.

(3) The very selective mGluR2/R3 agonist, L-CCG-I (Hayashi et al., 1992; Pin et al., 1994), was the most potent agonist in inducing $\mathrm{Ca}^{2+}$ channel inhibition.

(4) The lack of efficacy of L-APB on $\mathrm{Ca}^{2+}$ channels ruled out the implication of mGluR4, mGluR6, and mGluR7.

(5) Metabotropic GluRs coupled to PLC have been found to be either sensitive or insensitive to PTX, depending on the system (Pin et al., 1993). In primary cultures of cerebellar granule cells (Nicoletti et al., 1988), hippocampal or striatal neurons (Ambrosini and Meldolesi, 1989), high concentration of PTX $(1 \mu \mathrm{g} / \mathrm{ml})$ was reported to only partially inhibit stimulation of InsP mctabolism induced by glutamate or quisqualate. On the other hand, $1 \mu \mathrm{g}$ PTX in cultured striatal neurons (Prezeau et

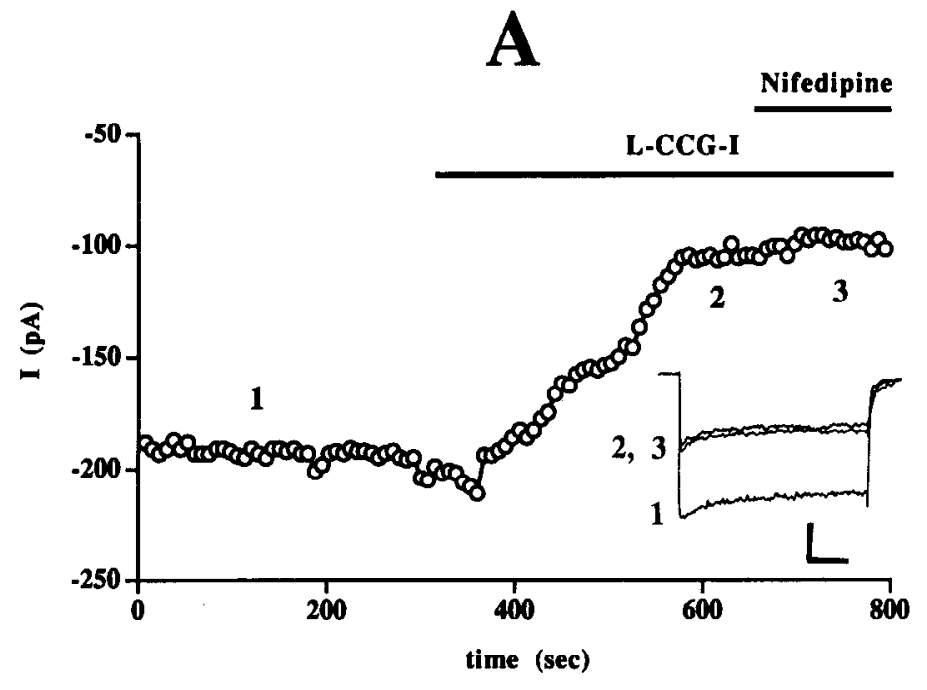

B

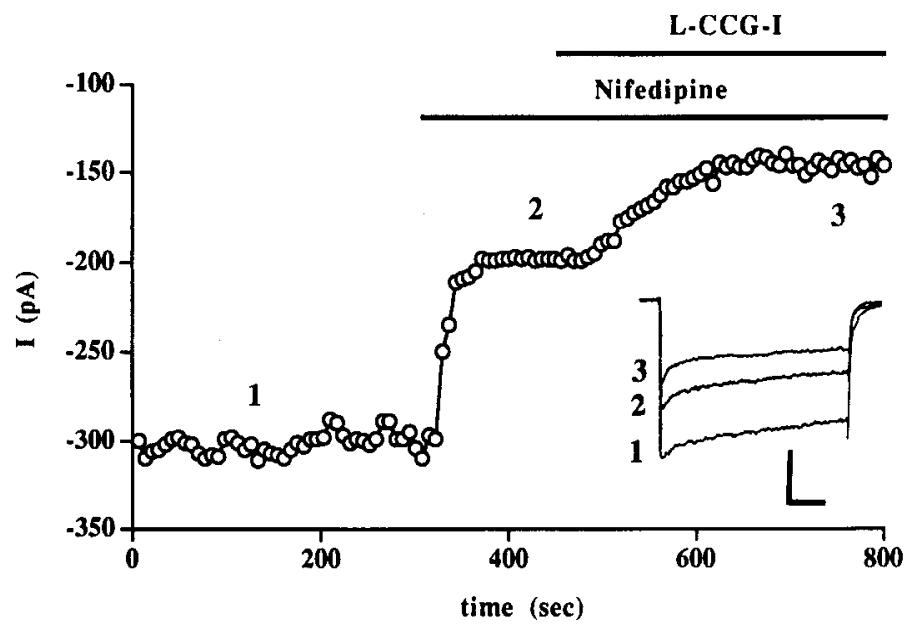

Figure 8. Inhibition of whole-cell calcium currents by L-CCG-I $(1 \mu \mathrm{M})$ and nifedipine $(10 \mu \mathrm{M}) . A$, Time course of the inhibitory effect of $\mathrm{L}-\mathrm{CCG}$ I. Inset shows $I_{\mathrm{Ca}}$ recorded under control condition $(I)$ and in the presence of L-CCG-I (2) and L-CCG-I + nifedipine (3). Notc the absence of nifedipine effect when nifedipine was applied on top of L-CCG-I. Similar results were observed in nine other cells. Calibration: $50 \mathrm{pA}$, 100 msec. $B$, Time course of the inhibitory effect of nifedipine and $\mathrm{L}-\mathrm{CCG}-\mathrm{I}+$ nifedipine. Inset shows $I_{\mathrm{Ca}}$ recorded under control condition (1) and in the presence of nifedipine (2) and L-CCG-I + nifedipine (3). Calibration: $100 \mathrm{pA}, 100 \mathrm{msec}$. Note that L-CCG-I induced additional inhibition of $I_{\mathrm{Ca}}$ when it was applied on top of nifedipine. Similar results were observed in nine other cells.

al., 1992) and only lng of the toxin in CHO cells (Tanabe et al., 1992) completely reversed glutamate-induced inhibition of adenylyl cyclase. Taken together, these observations are consistent with a lower PTX sensitivity of G-proteins coupled to mGluR $1 / R 5$ than those (probably $G_{i}$ - or $G_{o}$-like proteins) coupled to $\mathrm{mGluR} 2 / \mathrm{R} 3$. In our preparation, relatively low concentration $(200 \mathrm{ng} / \mathrm{ml})$ of PTX completely inhibited the mGluR effects on $\mathrm{Ca}^{2+}$ channels, suggesting a preferential role for mGluR2/R3 via a $\mathrm{G}_{i}$ - or $\mathrm{G}_{0}$-like protein.

(6) In neuronal cultures, the protein kinase $\mathrm{C}$ activator PDBU has been shown to attenuate mGluR1/R5-stimulated InsP synthesis (Canonico et al., 1988; Manzoni et al., 1990b) but not 
mGluR2 like-induced adenylyl cyclase inhibition (Prezeau et al., 1992). Here we found that the inhibition of $\mathrm{Ca}^{2+}$ channels by mGluR agonists was not affected by PDBU, reinforcing the idea that this effect was mediated by mGluR2/R3.

The features of the $\mathrm{Ca}^{2+}$ channel presently inhibited by mGluR agonists were similar to those of $\mathrm{L}$-type $\mathrm{Ca}^{2+}$ channels previously characterized in cultured cerebellar granule cells isolated from rat (Bossu et al., 1994). Because of the facilitatory effect of BAY K 8644 on the channel activation, we performed our pharmacological tests in the presence of the dihydropyridine agonist. Our cell-attached experiments are consistent with our whole-cell recordings showing that mGluR2/R3 receptors inhibit L-type $I_{\mathrm{c} a}$. Our whole-cell recordings also indicate that mGluR2/R3 receptors inhibit non-L-type $I_{\mathrm{Ca}}$. It is possible that this non-L-type $I_{\mathrm{Ca}}$ originated from $\mathrm{N}$-type $\mathrm{Ca}^{2+}$ channel activity since such current has been shown to be downregulated by mGluRs in CA3 pyramidal neurons (Swartz and Bean, 1992; Sahara and Westbrook, 1993). Our observations are also consistent with whole-cell recordings obtained by others in neocortical (Sayer ct al., 1992) and hippocampal ncurons (Sahara and Westbrook, 1993).

Because mGluR-induced inhibition of L-type $\mathrm{Ca}^{2+}$ channels was observed in the cell-attached recording configuration, a transduction mechanism was likely to be involved in this effect. The following observations suggested that none of the classical diffusible second messengers are potential candidates.

(1) L-Type $\mathrm{Ca}^{2}$ | channels need to be phosphorylated in order to be activated by membrane depolarization (Armstrong and Eckert, 1987; Sculptoreanu et al., 1993). cAMP-dependent kinase seems to be a good candidate for such a control (same references). Consistent with this hypothesis, we found an upregulation of L-type $\mathrm{Ca}^{2+}$ channels by IBMX and no significant rundown of $I_{\mathrm{Ca}}$ in the presence of intracellular cAMP. $1 S, 3 \mathrm{R} t$ ACPD almost abolished $\mathrm{Ca}^{2+}$ channel activity, even in the presence of IBMX and decreased cAMP formation in such a small proportion ( $15 \%$ decrease) that this change could not explain its electrophysiological correlate $\left(61 \%\right.$ to $100 \%$ decrease in $\mathrm{Ca}^{2+}$ channel $N P_{o}$ ). High concentration (1 mM) of intracellular cAMP did not change the inhibitory effect of L-CCG-I on $I_{\mathrm{Ca}}$ in our whole-cell experiments. Therefore, although $1 S, 3 R t$-ACPDinduced inhibition of L-type $\mathrm{Ca}^{2+}$ channels seemed to be mediated by mGluR2/R3, this effect did not probably result from adenylyl cyclase inhibition. Note that in order to significantly inhibit cAMP production by $\mathrm{mGluR} 2 / \mathrm{R} 3$ stimulation, it is necessary to activate adenylyl cyclase strongly with forskolin previously (Prezeau et al., 1992; Tanabe et al., 1992).

(2) Both up- and downregulations of L-type $\mathrm{Ca}^{2+}$ channel by protein kinase $C$ have been observed in vertebrate neurons. Phorbol esters suppress the high threshold $\mathrm{Ca}^{2+}$ current in hippocampal neurons (Doerner et al., 1990) and increased the $\mathrm{Ca}^{2+}$ current in frog sympathetic neurons (Bley and Tsien, 1990; Yang and Tsien, 1993). As mGluR1/R5 are known to activate PKC in incubated neurons, we tested this hypothesis. In our preparation, L-type $\mathrm{Ca}^{2+}$ channels were not significantly sensitive to the PKC activator, PDBU. Furthermore, PDBU did not significantly alter $1 S, 3 R t$-ACPD effects on $\mathrm{Ca}^{2+}$ channel activity. Finally, the mGluR 1 agonist, quisqualate, at concentration that markedly increased IP3 formation and therefore probably diacylglycerol synthesis and $\mathrm{Ca}^{2+}$ release from intracellular stores, induced poor inhibition if any of L-type $\mathrm{Ca}^{2+}$ channels.

Along the same argument, dephosphorylation of L-type $\mathrm{Ca}^{2+}$ channels should also result in channel inhibition and indeed direct or indirect implication of protein phosphatases in the regulation of $\mathrm{L}-$ type $\mathrm{Ca}^{2+}$ channels has been proposed (see Armstrong and White, 1992). We found that okadaic acid, at concentration where the toxin inhibits both protein phosphatase 1 and $2 \mathrm{~A}$, did not suppress mGluR-induced inhibition of L-type $\mathrm{Ca}^{2+}$ channels. The possibility that other phosphatases could be involved is however not excluded.

Intracellular $\mathrm{Ca}^{2+}$ downregulates $\mathrm{Ca}^{2+}$ activity (Bossu et al., 1989; Kalman et al., 1988; Yue et al., 1990). Since our experiments were performed in external $\mathrm{Ca}^{2+}$-free medium (both bath and patch-pipette), one can rule out the possibility that the mGluR-induced inhibition of L-type $\mathrm{Ca}^{2+}$ channels resulted from $\mathrm{Ca}^{2+}$ entry. An alternative possibility might be that stimulation of mGluRs coupled to phospholipase C inhibited L-type $\mathrm{Ca}^{2+}$ channels by releasing $\mathrm{Ca}^{2+}$ from intracellular IP3-sensitive stores. This hypothesis seems also unlikely since the pharmacology of the inhibitory effect of mGluRs on L-type $\mathrm{Ca}^{2+}$ channels matched the one of mGluR2/R3 rather than mGluR1/R5.

The consensus of results today would be that mGluRs, like muscarinic receptors (Bernhcim et al., 1991; Mathic et al., 1992), modulate $\mathrm{Ca}^{2+}$ channels through two independent unidentified pathways: a fast and membrane-delimited pathway that selectively inhibits N-type channels (Sahara and Westbrook, 1993; Swartz and Bean, 1992) and a slower $\mathrm{Ca}^{2+}$-dependent pathway that inhibits $\mathrm{L}$ - and $\mathrm{N}$-type channels through a second messenger (Sahara and Westbrook, 1993; Sayer et al., 1992). Our results are consistent with this assumption. The latency of the effect was always in the order of several minutes, suggesting mobilization of a diffusible second messenger, although none of the classical diffusible cytosolic second messengers that we tested appeared to be involved.

Several reports have suggested a direct inhibition of neuronal L-type $\mathrm{Ca}^{2+}$ channels by a PTX-sensitive G-protein (Dolphin and Scott, 1989; Haws et al., 1993). Since inhibition of L-type $\mathrm{Ca}^{2+}$ channels by mGluR stimulation could be prevented by PTX treatment and since no classical diffusible messenger seemed to be involved, a simple hypothesis would be that a $G_{o}$ or $G_{i}$ like protein directly blocked the channel. Such a hypothesis would be in agreement with the one of Lester and Jahr (1990) in hippocampal cells and with the latency of the effects obtained in our experiments, assuming that the involved putative G-protein diffused to a certain distance from the receptor within the plasma membrane. An alternative hypothesis would be that lipid-soluble messengers, such as lipoxygenase metabolites of arachidonic acid, which are known to directly modulate $\mathrm{K}^{+}$ channels (Piomelli and Greengard, 1990), also affect $\mathrm{Ca}^{2+}$ channels. However, at the moment no such mechanism has been found.

Stimulation of mGluR1/R5 increases the intracellular $\mathrm{Ca}^{2+}$ concentration via mobilization of the IP3 pathway. We showed elsewhere (Bossu et al., 1992; Chavis et al., 1994) that in addition to this pathway mGluR $1 / \mathrm{R} 5$ can increase the intracellular $\mathrm{Ca}^{2+}$ concentration in cerebellar granule cells by activating L-type $\mathrm{Ca}^{2+}$ channels via a PTX-insensitive second messenger pathway. Conversely, we show here that activation of mGluR2/R3 blocks $\mathrm{Ca}^{2+}$ entry. Such a dual processes would provide an original physiological control of intracellular $\mathrm{Ca}^{2+}$ via a single neurotransmitter (glutamate) acting on two different receptors (mGluR1/R5 and mGluR2/R3) coupled to different G-proteins (PTX-sensitive or -insensitive). This modulation may play an important role in the control of cell firing and synaptic plasticity in glutamatergic networks. 


\section{References}

Ambrosini A, Meldolesi J (1989) Muscarinic and quisqualate receptorinduced phosphoinositide hydrolysis in primary cultures of striatal and hippocampal neurons. Evidence for differential mechanisms of activation. J Neurochem 53:825-833.

Armstrong D, Eckert R (1987) Voltage-activated calcium channels that must be phosphorylated to respond to membrane depolarization. Proc Natl Acad Sci USA 84:2518-2522

Armstrong $D$, White $R$ (1992) An enzymatic mechanism for potassium channel stimulation through pertussis toxin-sensitive $G$ proteins. Trends Neurosci 15:403-408.

Artalejo CR, Ariano MA, Periman RL, Fox AP (1990) Activation of facilitation calcium channels in chromaffin cells by D1 dopamine receptors through a cAMP/protein kinase A-dependent mechanism. Nature 348:239-242.

Bernheim L, Beech DJ, Hille B (1991) A diffusible messenger mediates one of the pathways coupling receptors to calcium channels in rat sympathetic neurons. Neuron 6:859-867.

Bley KR, Tsien RW (1990) Inhibition of $\mathrm{Ca}^{2+}$ and $\mathrm{K}^{+}$channels in sympathetic neurons by neuropeptides and other ganglionic transmitters. Neuron 4:379-391.

Bossu J-L, Rodeau J-L, Feltz A (1989) Decay kinetics of calcium currents in rat sensory neurones: analysis at two internal free calcium concentrations. Pfluegers Arch 414:89-91.

Bossu J-L, Fagni L, Nooney JM, Bockaert J, Feltz A (1992) Metabotropic glutamate receptor stimulation increascs calcium currents in rat cerebellar granule cells. Soc Neurosci Abstr 18:1272.

Bossu J-L, De Waard M, Fagni L, Tanzi F, Feltz A (1994) Characteristics of calcium channels responsible for voltage-activated calcium entry in rat cerebellar granule cells. Eur J Neurosci 6:335-344.

Canonico PL, Favit A, Catania MV, Nicoletti F (1988) Phorbol esters attenuate glutamate-stimulates inositol phospholipid hydrolysis in neuronal cultures. J Neurochem 51:1049-1053.

Charpak S, Gähwiler BH, Do K, Knopfel T (1990) Potassium conductances in hippocampal neurons blocked by excitatory amino-acid transmitters. Nature 347:765-767.

Chavis P, Nooney JM, Bockaert J, Fagni L, Feltz A, Bossu JL (1994) Facilitatory coupling between a glutamate metabotropic receptor and dihydropyridine-sensitive calcium channels in cultured cerebellar granule cells. J Neurosci, in press.

Doerner D, Abdel-Latif M, Rogers TB, Alger BE (1990) Protein kinase $\mathrm{C}$-dependent and independent effects of phorbol esters on hippocampal calcium channel current. J Neurosci 10:1699-1706.

Dolphin AC, Scott RH (1989) Interaction between calcium channel ligands and guanine nucleotides in culture rat sensory and sympathetic neurones. J Physiol (Lond) 413:271-288.

Fagni L, Bossu JL, Bockaert J (1991) Activation of a large-conductance $\mathrm{Ca}^{2+}$-dependent $\mathrm{K}^{+}$channel by stimulation of glutamate phosphoinositide-coupled receptors in cultured cerebellar granule cells. Eur J Neurosci 3:778-789.

Forti L, Pietrobon D (1993) Functional diversity of L-type calcium channels in rat cerebellar neurons. Neuron 10:437-450.

Hartzell HC, Méry P-F, Fischmeister R, Szabo G (1991) Sympathetic regulation of cardiac calcium current is due exclusivcly to cAMPdependent phosphorylation. Nature 351:573-576.

Haws CM, Slesinger PA, Lansman JB (1993) Dihydropyridine- and $\omega$-conotoxin-sensitive $\mathrm{Ca}^{2+}$ currents in cerebellar neurons: persistent block of L-type channels by a pertussis toxin-sensitive G-protein. $\mathbf{J}$ Neurosci 13:1148-1158.

Hayashi Y, Tanabe Y, Aramori I, Masu M, Shimamoto K, Ohfune, Y Nakanishi S (1992) Agonist analysis of 2-(carboxycyclopropyl)glycine isomers for cloned metabotropic glutamate receptor subtypes expressed in Chinese hamster ovary cells. Br J Pharmacol 107:539-543.

Ishida M, Akagi N, Shimamoto K, Ohfne Y, Shinozaki H (1990) A potent metabotropic glutamate receptor agonist: electrophysiological actions of a conformationally restricted glutamate analog in rat spinal cord and Xenopus oocytes. Brain Res 537:311-314.

Kalman D, O'Lague PH, Erxleben C, Armstrong DL (1988) Calciumdependent inactivation of the dihydropyridine-sensitive calcium channels in GH3 cells. J Gen Physiol 92:531-548.

Lacerda AE, Rampe D, Brown AM (1988) Effects of protein kinase $C$ activators on cardiac $\mathrm{Ca}^{2+}$ channels. Nature 335:249-251.

Lester RA, Jahr CE (1990) Quisqualate receptor-mediated depression of calcium currents in hippocampal neurons. Neuron 4:741-749.

Manzoni O, Fagni L, Pin JP, Rassendren F, Poulat F, Sladeczek F,
Bockaert J (1990a) (Trans)-1-amino-cyclopentyl-1,3-dicarboxylate stimulates quisqualate phosphoinositide-coupled receptors but not ionotropic glutamate receptors in striatal neurons and Xenopus oocytes. Mol Pharmacol 38:1-6.

Manzoni O, Finiels-Marlier F, Sassetti I, Bockaert J, Le Peuch C, Sladeczek F (1990b) The glutamate receptor of the Qp-type activates protein kinase-C and is regulated by protein kinase- $C$. Neurosci Lett 109:146-151.

Manzoni O, Poulat F, Do E, Sahuquet A, Sassetti I, Bockaert J, Sladeczek F (1991) Pharmacological characterization of the quisqualate receptor coupled to phospholipase C (Qp) in striatal neurons. Eur J Pharmacol (Mol Pharmacol Sec) 207:231-241.

Mathie A, Bernheim L, Hille B (1992) Inhibition of N- and L-type calcium channels by muscarinic receptor activation in rat sympathetic neurons. Neuron 8:907-914.

Nakagawa Y, Saitoh K, Ishida M, Shinozaki H (1990) $(2 S, 3 S, 4 S) \alpha-$ (carboxycyclopropyl)glycine is a novel agonist of metabotropic glutamate receptors. Eur J Pharmacol 184:205-206.

Nakanishi S (1992) Molecular diversity of glutamate receptors and implications for brain functions. Science 258:597-603.

Nicoletti F, Wrobleski JT, Fadda E, Costa E (1988) Pertussis toxin inhibits signal transduction at a specific metabotropic glutamate receptor in primary cultures of cerebellar granule cells. Neuropharmacology 27:551-556.

Pacellli GJ, Kelso SR (1991) Trans-ACPD reduces multiple components of synaptic transmission in the rat hippocampus. Neurosci Lett 132:267-269.

Pietrobon D, Forti L, Tottene A, Moretti A (1993) Functional diversity of dihydropyridine and $\omega$-conotoxin-GVIA-insensitive calcium channels in rat cerebellar granules. Soc Neurosci Abstr 19:607.7.

Pin J-P, Fagni L, Bockaert J (1993) Metabotropic glutamate receptors: targets for new neuropharmacologically active drugs. Curr Drugs Neurodegen Disord 1:111-137.

Pin J-P, Joly C, Heinemann SF, Bockaert J (1994) Domains involved in the specificity of $G$ protein activation in phospholipase $C$-coupled metabotropic glutamate receptors. EMBO J 13:342-348.

Piomelli D, Greengard P (1990) Lipoxygenase metabolites of arachidonic acid in neuronal transmembrane signalling. Trends Pharmacol Sci 11:367-373.

Prezeau L, Manzoni O, Homburger V, Sladeczek F, Curry K, Bockaert J (1992) Characterization of a metabotropic glutamate receptor: direct negative coupling to a pertussis toxin $G$ protein. Proc Natl Acad Sci USA 89:8040-8044.

Sahara Y, Westbrook GL (1993) Modulation of calcium currents by a metabotropic glutamate receptor involves fast and slow kinetic components in cultured hippocampal neurons. J Neurosci 13:30413050 .

Sayer RJ, Schwindt PC, Crill WE (1992) Metabotropic glutamate receptor-mediated suppression of L-type calcium current in acutely isolated neocortical neurons. J Neurophysiol 68:833-843.

Sculptoreanu A, Scheuer T, Caterall WA (1993) Voltage-dependent potentiation of $\mathrm{L}$-type $\mathrm{Ca}^{2+}$ channels due to phosphorylation by cAMPdependent protein kinase. Nature 364:240-243.

Seeburg PH (1993) The TIPS/TINS lecture: the molecular biology of mammalian glutamate receptor channels. Trends Pharmacol Sci 14: 297-303.

Shigemoto R (1993) Structure, function and localization of the metabotropic glutamate receptor subtypes. J Neurochem 61:S123C.

Shimamoto K, Ishida M, Shinozaki H, Ohfume Y (1991) Synthesis of four diastereomeric L-2-(carboxycyclopropyl)glycines. Conformationally constrained L-glutamate analogues. J Org Chem 546:41674176.

Sladcczck F, Pin JP, Récasens M, Bockaert J, Weiss S (1985) Glutamate stimulates inositol phosphate formation in striatal neurones. Nature 317:717-719.

Slesinger PA, Lansman JB (1991) Inactivation of calcium currents in granule cells cultured form mouse cerebellum. J Physiol (Lond) 435: 101-121.

Stratton KR, Worley PF, Baraban JM (1989) Excitation of hippocampal neurons by stimulation of glutamate Qp receptors. Eur J Pharmacol 173:235-237.

Swartz KJ, Bean BP (1992) Inhibition of calcium channels in rat CA3 pyramidal neurons by a metabotropic glutamate receptor. J Neurosci 12:4358-4371.

Tanabe Y, Ito I, Sugiyama H (1991) Possible heterogeneity of meta- 
botropic glutamate receptors induced in Xenopus oocytes by rat brain mRNA. Neurosci Res 10:71-77.

Tanabe Y, Masu M, Ishii T, Shigemoto R, Nakanishi S (1992) A family of metabotropic receptors. Neuron 8:169-179.

Van-Vliet BJ, Sebben M, Dumuis A, Gabrion J, Bockaert J, Pin JP (1989) Endogenous amino acid release from cultured cerebellar neuronal cells: effect of tetanus toxin on glutamate release. J Neurochem 52:1229-1239.

Weiss S, Sebben M, Garcia-Sainz JA, Bockaert J (1985) D2-Dopamine receptor-mediated inhibition of cyclic AMP formation in striatal neurons in primary culture. Mol Pharmacol 27:595-599.

Weiss S, Pin J-P, Sebben M, Kemp D, Sladeczek F, Gabrion J, Bockaert J (1986) Synaptogenesis of cultured striatal neurones in serum-free medium: a morphological and biochemical study. Proc Natl Acad Sci USA 83:2238-2242.

Yang J, Tsien RW (1993) Enhancement of N- and L-type calcium channel currents by protein kinase $\mathrm{C}$ in frog sympathetic neurons. Neuron 10:127-136.

Yue DT, Backx PH, Imredy JP (1990) Calcium-sensitive inactivation in the gating of single calcium channels. Science 250:1735-1738.

Zhang JF, Randall AD, Ellinor PT, Horne WA, Sather WA, Tanabe T, Schwarz TL, Tsien RW (1993) Distinctive pharmacology and kinetics of cloned neuronal $\mathrm{Ca}^{2+}$ channels and their possible counterparts in mammalian CNS neurons. Neuropharmacology 32:10751088. 